\title{
FAKTOR-FAKTOR PENENTU PENINGKATAN KINERJA PEJABAT PEMBUAT KOMITMEN (PPK) PADASATKER APBN DAN SKPD PROVINSI KALIMANTAN TIMUR
}

\author{
Rizali Rahmawanto $^{1}$,A. Wicaksono ${ }^{2}$ \& Sugeng P. Budio ${ }^{3}$ \\ ${ }^{1,2 \& 3}$ Fakultas Teknik Jurusan Teknik Sipil Universitas Brawijaya Malang \\ Alamat Korespondensi : Jl. MT. Haryono No 167 Malang, Indonesia
}

\begin{abstract}
This research aims to find the most dominant factor that determines the Committing Officer (CO) to improve their performance, to determine the performance appraisal field coordinator Committing Officer (CO), to know how to improve the performance of the Committing Officer (CO) to achieve targets as per the Contract Performance.

Validity test results indicate that all variables are as valid as each item has a value of Pearson Correlatian amounted to less than 0.05, and the test showed that the value of Cronbach's Alpha greater than 0.6 so variable and item questionnaire is compliant study. Dominant factor test results using factor analysis showed the dominant factor as a determinant of Committing Officer in improving the performance seen from the level of satisfaction is the location factor $(55.124 \%)$, factor equipment $(19.034 \%)$, the budget factor $(15.718 \%)$, personnel factor $(6.716 \%)$, partner factor $(3.408 \%)$.

While the dominant factor based on the level of interest is the location factor $(69.252 \%)$, the budget factor $(20.992 \%)$, personnel factor $(4.426 \%)$, equipment factor $(3.523 \%)$ and the partner factor $(1.807 \%)$.
\end{abstract}

Keywords: Committing Officer (CO), Performance, Factor Dominant

\section{PENDAHULUAN}

Sesuai dengan Undang-undang Nomor 39 tahun 2008 tentang Kementerian Negara dan Peraturan Presiden Nomor 47 tahun 2009, Direktorat Jenderal Bina Marga memiliki rugas pokok mampu menyediakan jaringan jalan yang yang andal, terpadu \& berkelanjutan serta mampu mendukung pertumbuhan ekonomi dan kesejahteraan sosial demi tercapainya Indonesia yang Aman, Adil dan Demokratis serta Lebih Sejahtera melalui pengaturan, pembinaan, pembangunan, pengusahaan dan pengawasan yang meliputi wilayah Negara Kesatuan Republik Indonesia.

Berdasarkan kebijakan tersebut perkembangan konstruksi khususnya jalan raya makin meningkat disetiap daerah, demikian pula pada wilayah Kalimantan Timur.

Dalam hal proyek pembangunan jalan ini, salah satu sumber daya manusia yang berperan penting adalah Pejabat Pembuat Komitmen (PPK) yang tergabung dalam Satuan Kerja disetiap propinsi dibawah Diroktorat Jenderal Bina Marga. PPK yang dulu hanya bertugas sebagai pelaksana paket kegiatan namun pada tahun 2010 juga sebagai manajer ruas yang bertanggung jawab penuh terhadap link yang ditangani.

Mengingat begitu pentingnya peran PPK, dalam penelitian ini ditekankan pada faktor-faktor yang menjadi penentu PPK dalam pencapaian target kerja yang tertuang dalam pasal-pasal Kontrak Kinerja. Dengan begitu dapat diketahui sejauh mana signifikansi kinerja PPK terhadap keberhasilan proyek dalam hal waktu, biaya dan waktu.

\section{Tinjauan Umum Pejabat Pembuat Komitmen}

Pejabat Pembuat Komitmen (PPK) bisa juga disebut sebagai Manajer Ruas/Area pada masingmasing link kegiatan mereka. Konsep Manajer Ruas/ Area lahir dalam upaya penyempurnaan pola dan manajemen penanganan jalan dan jembatan demi mengakomodir perkembangan kondisi jalan dan 
jembatan maupun mengakomodir apresiasi masyarakat terhadap administrasi penanganan jalan dan jembatan.

Secara umum, Manajer Ruas/Area bertanggungjawab terhadap pengawasan, pelaporan, dan penanganan ruas jalan di wilayah kerjanya, sehingga upaya pencapaian zero hole pot dan penanganan crack jalan dapat dilakukan dalam waktu secepatnya serta pengawalan kondisi jaringan jalan nasional agar tetap prima.

Kontrak Kinerja

Undang-Undang Nomor 17 Tahun 2003 tentang Keuangan Negara telah mengamanatkan penerapan anggaran berbasis prestasi kerja. Hal tersebut menuntut perlunya suatu sistem pengukuran yang dapat mencerminkan adanya akuntabilitas kinerja. Balanced Scorecard (BSC) sebagai alat pengukuran kinerja Pengukuran kinerja dimaksudkan agar pencapaian tujuan organisasi dapat dikelola secara lebih efektif dan efsien. Selama ini masih ada anggapan bahwa BSC hanya menambah beban kerja, bahkan berimplikasi pada punishment apabila target kinerja tidak tercapai. Padahal, jika BSC telah berhasil diimplementasikan,BSC akan berfungsi menjadi suatu alat manajemen strategi bagi setiap pimpinan unit organisasi.

\section{METODOLOGI PENELITIAN}

Obyek studi adalah Pejabat Pembuat Komitmen (PPK) yang tergabung dalam Satuan kerja APBN dan SKPD di Provinsi Kalimantan Timur.

Penelitian dilakukan di Kota Samarinda yaitu pada Dinas Pekerjaan Umum Provinsi Kalimantan Timur Satker Pelaksanaan Jalan Nasional Wilayah I, II, III dan SKPD.

Teknik penentuan sampel yang digunakan adalah Purposive Sampling dimana penelitian ini tidak dilakukan pada seluruh populasi, tapi terfokus pada target. Purposive Sampling adalah teknik penetuan sampel dengan mempertimbangkan kriteria-kriteria tertentu yang telah ditentukan sebelumnya terhadap obyek yang sesuai dengan tujuan penelitian dalam hal ini penelitian dilakukan pada instansi Dinas Pekerjaan Umum Kalimantan Timur.

Jenis penelitian yang dilakukan adalah penelitian survey yang bertujuan untuk mencari tentang fakta dan sifat - sifat suatu populasi atau daerah tertentu secara sitimatis, faktual dan teliti. Variabel yang diteliti terbatas atau tertentu saja, tetapi dilakukan secara meluas pada suatu populasi daerah tersebut.

Data yang digunakan dalam penelitian ini adalah data primer dan data sekunder. Data primer dilakukan dengan wawancara dan menggunakan daftar pertanyaan yang telah dipersiapkan/kuisoner. Data sekunder diperoleh dari dokumen instansi terkait serta publikasi lainnya yang memuat informasi yang mendukung penelitian ini.

Berdasarkan pendekatan yang digunakan, penelitian ini dikombinasikan antara kualitatif dan kuantitatif. Data kualitatif adalah data yang membentuk kalimat, kata atau gambar, sedangkan data kuantitatif adalah kata yang berbentuk angka atau data kualitatif yang dibuat angka.

\section{Uji Instrumen Penelitian dengan Validitas dan Reliabilitas}

Uji validitas digunakan untuk mengukur seberapa cermat suatu test melaksanakan fungsi ukurnya. Dalam penelitian ini digunakan uji validitas item dengan menggunakan kriteria internal yaitu membandingkan kesesuaian tiap komponen pertanyaan dengan skor keseluruhan tiap komponen pertanyaan dengan skor total keseluruhan test. Uji validitas juga merupakan kemampuan dari indikator-indikator untuk mengukur tingkat keakuratan sebuah konsep. Artinya apakah konsep yang telah dibangun tersebut sudah valid atau belum. Uji ini melibatkan para ahli (ahli pemasaran, ahli statistik) dan pihak yang berkompeten (calon responden) untuk memberi komentar dan saran terhadap indikator yang dijabarkan dalam item pertanyaan (Sugiyono, 1999).

Reliabilitas adalah indeks yang menunjukkan sejauh mana suatu alat pengukur dapat dipercaya/ diandalkan. Reliabilitas menunjukkan konsistensi suatu alat pengukur didalam mengukur gejala yang sama, dalam beberapa kali pelaksanaan pengukuran teknik a Cronbach pada SPSS. Dengan taraf signifikansi 95\% suatu variabel dikatakan reliable bila variabel tersebut mempunyai koefisien a Cronbach =0,60.

\section{Analisis Faktor (Faktor Analysis)}

Analisis Faktor (Faktor Analysis) Analisis Faktor (Faktor Analysis) merupakan suatu teknik statistik multivariate yang digunakan untuk mengurangi 
(reduction) dan meringkas (summarization) semua variabel terikat dan saling berketergantungan. Hubungan ketergantungan antara satu variabel dengan yang lain yang akan diuji untuk diidentifikasikan dimensi atau faktornya.

Tahapan dalam analisa faktor (Santoso,2001) urutan sebagaiberikut:

- Memilih variabel yang layak untuk analisis faktor

Tahap pertama pada analisis faktor adalah menilai variabel mana yang dianggap layak untuk dimasukkan dalam analisis selanjutnya.Beberapa pengukuran yang dapat dilakukan antara lain dengan memperhatikan, nilai KMO dan nilai MSA.

\section{- Susun ekstraksi variabel}

Setelah sejumlah variabel terpilih, maka dilakukan ekstraksi variable menjadi beberapa kelompok faktor, dengan menggunakan metode PCA (Principal Component Analysis). Penentuan terbentuknya jumlah kelompok faktor dilakukan dengan melihat nilai eigen yang menyatakan kepentingan relatif masing-masing faktor dalam menghitung varian dari varibale-variabel yang dianalisis. Nilai eigen (eigen value) dibawah 1 tidak dapat digunakan dalam menghitung jumlah faktor yang terbentuk (Santoso, 2004).

\section{- Rotasi Kelompok Faktor}

Setelah diketahui jumlah kelompok faktor yang terbentuk, maka tabel matriks komponen akan menunjukkan distribusi variabel-variabel pada sejumlah kelompok faktor yang terbentuk. Angka-angka pada kelompok faktor tersebut disebut loading faktor yang menunjukkan korelasi antara variabel dan kelompok faktor.

\section{- Manamakan Kelompok Faktor}

Setelah terbentuk kelompok faktor, maka proses dilanjutkan dengan memberikan nama terhadap kelompok faktor tersebut. Tidak ada aturan khusus dalam penamaan ini, hanya saja penamaan dari suatu faktor hendaknya mencerminkan rariabel-variabel yang tergabung/terbentuk di dalamnya.

\section{HASIL DAN PEMBAHASAN}

\section{Analisis Diskriptif Faktor-faktor yang Mempengaruhi Kinerja PPK berdasarkan tingkat kepuasan.}

Setelah pengisian kuesioner dilakukan analisis awal yaitu analisis diskriptif yaitu untuk menggambarkan kondisi sampel secara umum. Dalam penelitian ini untuk mengetahui seberapa besar faktor yang mempengaruhi kinerja PPK diukur dari skor yang terdapat dalam kuesioner yang meliputi penilaian terhadap: (1) personil, (2) Anggaran, (3) Peralatan, (4) Lokasi, (5) Rekanan

Secara lengkap hasil kuesioner faktor kinerja PPK dipandang dari tingkat kepuasan dapat dilihat dalam tabel 1.

Adapun persentase faktor-faktor yang mempengaruhi kinerja PPK dilihat dari tingkat kepuasan dapat dilihat pada gambar 1.

Tabel 1. Data faktor yang mempengaruhi kinerja PPK berdasarkan kepuasan.

\begin{tabular}{lllllllll}
\hline No & Variabel & Jml & Skor & Skor & \multicolumn{4}{c}{ Skor yan g diperoleh } \\
\cline { 6 - 9 } & & item & Max & Min & Tinggi & Rendah & Rata-rata & \% \\
\hline 1 & Personil & 4 & 20 & 4 & 15 & 10 & 12.00 & 60 \\
2 & Anggaran & 7 & 35 & 7 & 26 & 20 & 23.00 & 65.7143 \\
3 & Peralatan & 4 & 20 & 4 & 17 & 8 & 11.26 & 56.3158 \\
4 & Lokasi & 9 & 45 & 9 & 30 & 20 & 25.37 & 56.3743 \\
5 & Rekanan & 4 & 20 & 4 & 14 & 9 & 11.26 & 58.1579 \\
\hline & Total & 28 & 140 & 28 & & & 83.26 & \\
\hline
\end{tabular}




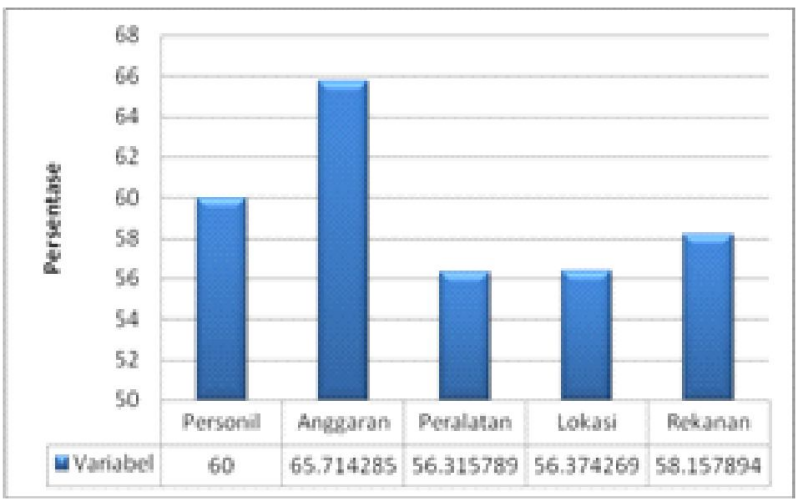

Gambar 1. Persentase faktor yang mempengaruhi kinerja PPk berdasrkan tingkat kepuasan

Dari gambar tersebut dapat dilihat bahwa variabel anggaran memberikan pengaruh yang cukup terhadap tingkat kepuasan dalam kinerja pejabat pembuat komitmen (PPK). Anggaran merupakan hal penting dalam pelaksanaan suatu kegiatan proyek, dana dengan jumlah dan penggunaan yang tepat mempengaruhi cepat lambatnya suatu proyek. Dari gambar 1 juga dapat dilihat dari secara keseluruhan tingkat kepuasan PPK terhadap faktor-faktor tersebut diatas masih kurang, ini ditunjukkan dengan rendahnya presentase angka yang diperoleh.

Analisis Diskriptif Faktor-faktor yang Mempengaruhi Kinerja PPK berdasarkan tingkat kepentingan

Hasil kuesioner Faktor-faktor yang mempengaruhi kinerja PPK menurut kepentingan juga dapat dilihat pada tabel 2 .

Tabel 2. Data faktor yang mempengaruhi kinerja PPK menurut tingkat kepentingan

\begin{tabular}{|c|c|c|c|c|c|c|c|c|}
\hline \multirow[t]{2}{*}{ No } & \multirow[t]{2}{*}{ Variabel } & \multirow{2}{*}{$\begin{array}{l}\text { Jml } \\
\text { item }\end{array}$} & \multirow{2}{*}{$\begin{array}{l}\text { Skor } \\
\text { Max }\end{array}$} & \multirow{2}{*}{$\begin{array}{l}\text { Skor } \\
\text { Min }\end{array}$} & \multicolumn{4}{|c|}{ Skor yan g diperoleh } \\
\hline & & & & & Tinggi & Rendah & Rata-rata & $\%$ \\
\hline 1 & Personil & 4 & 20 & 4 & 20 & 14 & 17.37 & 86.8421 \\
\hline 2 & Anggaran & 7 & 35 & 7 & 34 & 29 & 31.74 & 90.6767 \\
\hline 3 & Peralatan & 4 & 20 & 4 & 19 & 14 & 16.37 & 81.8421 \\
\hline 4 & Lokasi & 9 & 45 & 9 & 42 & 35 & 38.53 & 85.614 \\
\hline 5 & Rekanan & 4 & 20 & 4 & 20 & 14 & 17.37 & 86.8421 \\
\hline & Total & 28 & 140 & 28 & & & 121.37 & \\
\hline
\end{tabular}

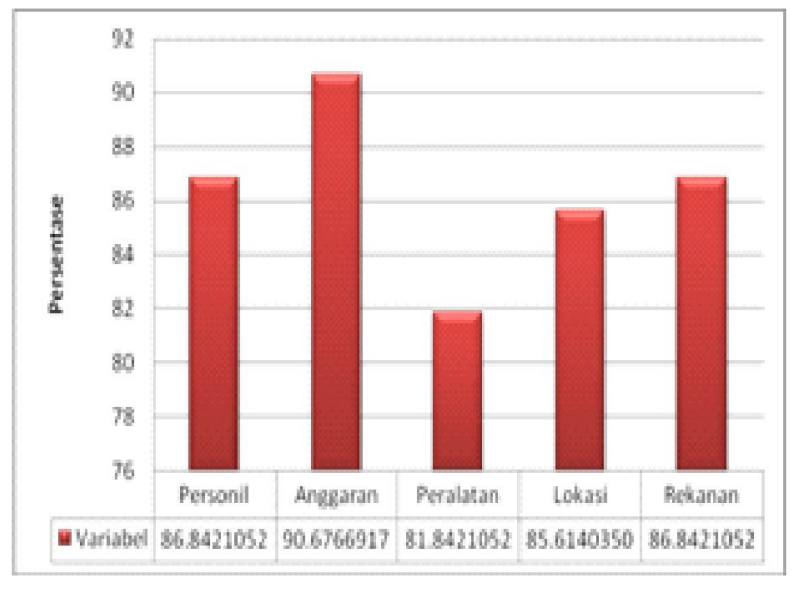

Gambar 2. Persentase faktor yang mempengaruhi kinerja PPk berdasarkan tingkat kepentingan

Dari gambar 2 dapat dilihat secara keseluruhan variable personil, anggaran, peralatan, lokasi dan rekanan merupan faktor yang penting dalam peningkatan kinerja PPK, namun faktor yang sangat mempengaruhi adalah anggaran dengan presentase sebesar 90,67\%.

\section{Hasil Uji Instrumen Penelitian Validitas dan Reliabilitas}

Uji validitas adalah pengujian yang dilakukan guna untuk mengetahui cermat suatu instrument dalam mengukur apa yang ingin di ukur. Dalam hal ini uji validitas dilakukan terhadap kuesioner yang telah disebar sebanyak 19 orang PPK dan 19 orang Kordinator Lapangan. Hasil Uji Validitas dapat dilihat pada tabel 3. Dari tabel tersebut diketahui bahwa seluruh variabel dan item kuesioner telah valid. karena setiap item memiliki nilai Pearson Correlatian sebesar kurang dari 0.05, sehingga variabel dan item pertanyaan ini boleh dilanjutkan atau telah memenuhi persyaratan penelitian. Sehingga dapat dikatakan 
hal yang menjadi faktor dominan yang mempengaruhi kinerja PPK.

Tabel 3 Rekap hasil validitas untuk seluruh variabel Pejabat Pembuat Komitmen (PPK)

\begin{tabular}{|c|c|c|c|c|c|c|c|c|}
\hline \multirow[t]{2}{*}{ No } & \multirow[t]{2}{*}{ Variabel } & \multirow{2}{*}{$\begin{array}{l}\text { Jml } \\
\text { item }\end{array}$} & \multirow{2}{*}{$\begin{array}{l}\text { Skor } \\
\text { Max }\end{array}$} & \multirow{2}{*}{$\begin{array}{l}\text { Skor } \\
\text { Min }\end{array}$} & \multicolumn{4}{|c|}{ Skor yan g diperoleh } \\
\hline & & & & & Tinggi & Rendah & Rata-rata & $\%$ \\
\hline 1 & Personil & 4 & 20 & 4 & 20 & 14 & 17.37 & 86.8421 \\
\hline 2 & Anggaran & 7 & 35 & 7 & 34 & 29 & 31.74 & 90.6767 \\
\hline 3 & Peralatan & 4 & 20 & 4 & 19 & 14 & 16.37 & 81.8421 \\
\hline 4 & Lokasi & 9 & 45 & 9 & 42 & 35 & 38.53 & 85.614 \\
\hline 5 & Rekanan & 4 & 20 & 4 & 20 & 14 & 17.37 & 86.8421 \\
\hline & Total & 28 & 140 & 28 & & & 121.37 & \\
\hline
\end{tabular}

Uji reliabilitas untuk menguji konsistensi alat ukur, yang dapat menunjukkan apakah hasilnya akan konsisten apabila dilakukan pengujian ulang. Berikut contoh variable personil pada tabel 4 dapat dikatakan reliabel karena nilai Cronbach's Alpha bernilai 0.744 yaitu lebih besar dari 0.6 yang merupakan nilai syarat dari reliabilitas
Tabel 4. Hasil reliabilitas variabel personil (X1)

Case Processing Summery

\begin{tabular}{ccll}
\hline & & $\mathrm{N}$ & $\%$ \\
\hline Cases & Valid & 19 & 100,0 \\
Excludeda $^{a}$ & 0 & .0 \\
Total & 19 & 100,0 \\
\hline
\end{tabular}

a. Listwise deteion based on all variables in the procedure

\section{Reliability Statistics}

\begin{tabular}{ll}
\hline $\begin{array}{l}\text { Cronbach's } \\
\text { Alpha }\end{array}$ & $\begin{array}{l}\text { N of } \\
\text { Items }\end{array}$ \\
\hline 744 & 4 \\
\hline
\end{tabular}

Kuesioner PPK

\begin{tabular}{lll}
\hline Variabel & Nilai Cronbach's Alpha ( lebih dari 0.6) & Kesimpulan \\
\hline Personil (X1) & 0.804 & Reliabilitas \\
Lokasi (X4) & 0.869 & Reliabilitas \\
Personil (X1) & 0.804 & Reliabilitas \\
Lokasi (X4) & 0.869 & Reliabilitas \\
Personil (X1) & 0.804 & Reliabilitas \\
\hline
\end{tabular}

Analisis faktor Dominan yang mempengaruhi kinerja pejabat pembuat komitmen (PPK) dilihat dari tingkat kepuasan

Dengan menggunakan analisis faktor dengan bantuan software SPSS didapatkan hasil secara keseluruhanterdapat faktor-faktor yang paling dominan berdasarkan tingkat kepuasan yang menjadi penentu PPK dalam meningkatkan performa mereka, secara berurutan adalah faktor faktor lokasi $(55,124 \%)$, faktor peralatan $(19,034 \%)$, faktor anggaran $(15,718 \%)$, faktor personil $(6,716 \%)$, faktor rekanan $(3,408 \%)$. 


\section{Faktor lokasi}

Faktor lokasi yaitu yang terdiri dari variabel lokasi (persentase kondisi jalan, panjang pemeliharaan jalan, panjang peningkatan jalan, panjang pelebaran jalan, persentase kerusakan jalan, persentase pemotongan rumput dan semak, persentase pembersihan saluran, persentase penambalan lubang, dan ketersediaan bahan di lokasi) merupakan faktor yang paling dominan dengan varians sebesar 55,124\%

Dari analisa tersebut, diketahui bahwa hal utama yang sering kali menjadi persoalan dalam pelaksanaan proyek adalah faktor lokasi. Khususnya dalam proyek pekerjaan jalan, lokasi merupakan titik awal dari pencapaian pekerjaan, mulai dari pekerjaan persiapan yang berpengaruh terhadap mobilitas material, tenaga kerja, alat-alat khususnya produktivitas alat berat dan sebagainya.

\section{Faktor peralatan}

Faktor peralatan yang terdiri dari variabel peralatan (ketersediaan peralatan yang dimiliki, ketersediaan tempat penyewaan peralatan, ketersediaan kendaraan operasional tenaga kerja lapangan, dan ketersediaan penunjang alat komunikasi) merupakan faktor yang paling dominan dengan varians sebesar $19,034 \%$.

Selain faktor lokasi, faktor peralatan memberikan pengaruh terhadap tingkat kepuasan kerja PPK. Jika peralatan yang dibutuhkan untuk pelaksanaan proyek tersedia dengan baik, sudah tentu efektivitas personil proyek dapat terlaksana baik. Ketersediaan peralatan yang diperlukan untuk mengerjakan konstruksi jalan baik jenis dan jumlahnya harus memenuhi kebutuhan pekerjaan konstruksi selama pelaksanaan dari awal sampai dengan selesainya fisik jalan dapat difungsikan / dimanfaatkan.

\section{Faktor Anggaran}

Faktor anggaran yaitu yang terdiri dari variabel anggaran (ketersediaan alokasi dana, ketersediaan waktu, proyek tepat waktu, proyek tepat biaya, laporan keuangan teraudit, persentase penuntasan temuan, dan persentase realisasi DIPA) merupakan faktor yang paling dominan dengan varians sebesar $15,718 \%$.
Dalam proyek konstruksi, anggaran merupakan hal yang sangat penting baik dalam perencanaa, pelaksanaan, pemeliharaan ataupun evaluasi proyek. Berdasarkan hasil wawancara dan kondisi lapangan, masalah anggaran seringkali menjadi persoalan.

Adapun persentase faktor dominan yang mempengaruhi kinerja PPK berdasarkan tingkat kepuasan dapat dilihat pada gambar 3.

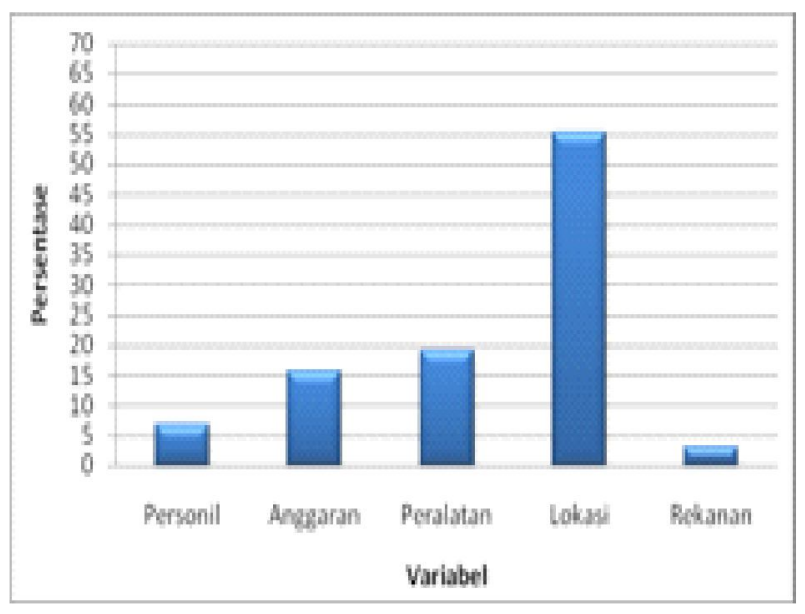

\section{Gambar 3. Persentase faktor dominan yang mempengaruhi kinerja PPK berdasarkan tingkat kepuasan}

\section{Analisis faktor Dominan yang mempengaruhi kinerja pejabat pembuat komitmen PPK berdasarkan tingkat kepentingan}

Sama dengan proses Analisis faktor Dominan yang mempengaruhi kinerja pejabat pembuat komitmen PPK berdasarkan tingkat kepuasan, juga dilakukan analisis faktor.

Dari hasil analisis secara keseluruhan, terdapat faktor-faktor yang paling dominan berdasarkan tingkat kepentingan yang menjadi penentu PPK dalam meningkatkan performa mereka, secara berurutan adalah faktor lokasi $(69,252 \%)$, faktor anggaran $(20,992 \%)$, faktor personil $(4,426 \%)$, faktor peralatan $(3,523 \%)$, dan faktor rekanan $(1,807 \%)$.

\section{Faktor lokasi}

Faktor lokasi yaitu yang terdiri dari variabel lokasi (persentase kondisijalan, panjang pemeliharaan jalan, panjang peningkatan jalan, panjang pelebaran jalan, 
persentase kerusakan jalan, persentase pemotongan rumput dan semak, persentase pembersihan saluran, persentase penambalan lubang, dan ketersediaan bahan di lokasi) merupakan faktor yang paling dominan dengan varians sebesar 69,252\%.

Dalam proyek konstruksi jalan, lokasi menjadi faktor utama yang paling penting dalam pelaksanaan proyek. Sebelum proyek tersebut di mulai sudah pasti diadakan studi lapangan untuk mengetahui bentuk topografi permukaan tanah, sehingga diketahui peralatan, bahan dan material yang dibutuhkan dalam perencanaan pembangunan, pelebaran jalan. Berdasarkan hasil wawancara terhadap responden, lokasi memang merupak hal utama yang meraka perhatikan dalam bekerja, karena semakin sulit medan/ lokasi proyek yang ditangani tentu makin besar efektivitas kerja mereka dan ini tentunya memberikan pengaruh terhadap kinerja PPK.

Menurut Tiong Iskandar, dalam jurnalnya yang berjudul analisisa kinerja operator alat berat pada pekerjaan galian timpunan pada proyek pembangunan jalan jalur lintas selatan, dinyatakan bahwa lokasi adalah faktor terpenting dalam hal penentu jumlah dan kapasitas alat berat yang digunakan sehingga mempengaruhi mutu, biaya dan waktu suatu proyek.

\section{Faktor Anggaran}

Faktor anggaran yaitu yang terdiri dari variabel anggaran (ketersediaan alokasi dana, ketersediaan waktu, proyek tepat waktu, proyek tepat biaya, laporan keuangan teraudit, persentase penuntasan temuan, dan persentase realisasi DIPA) merupakan faktor yang paling dominan dengan varians sebesar 20,992\% .

Dalam penyelenggaraan sebuah proyek, faktor biaya merupakan bahan pertimbangan utama karena biasanya menyangkut jumlah investasi besar yang harus ditanankan pemberi tugas yang rentan terhadap resiko kegagalan. Fluktuasi pembiayaan suatu konstruksi bjalan juga tidak lepas dari pengaruh situasi ekonomi yang mungkin dapat berupa kenaikan harga material, harga peralatan, dan upah, tenaga kerja. Karena inflasi, kenaikan biaya sebagai akibat pengembangan bunga bank, kesempitan modal kerja, atau penundaan pelaksaaanm kegiatan karena suatu keterlambatan. Di samping itu masih ada pengaruh yang datang dari masalah produktivitas, kemudian ketersediaan sarana dan prasarana awal lokasi proyek, atau kejadian khusus seperti sengketa hukum dan sebagainya.

Dari hasil penelitian menunjukkan bahwa faktor anggaran merupakan salah satu faktor yang sangat penting bagi peningkatan kinerja Pejabat Pembuat Komitmen. Adapun persentase faktor dominan yang mempengaruhi kinerja PPK berdasarkan tingkat kepentingan dapat dilihat pada gambar 4 .

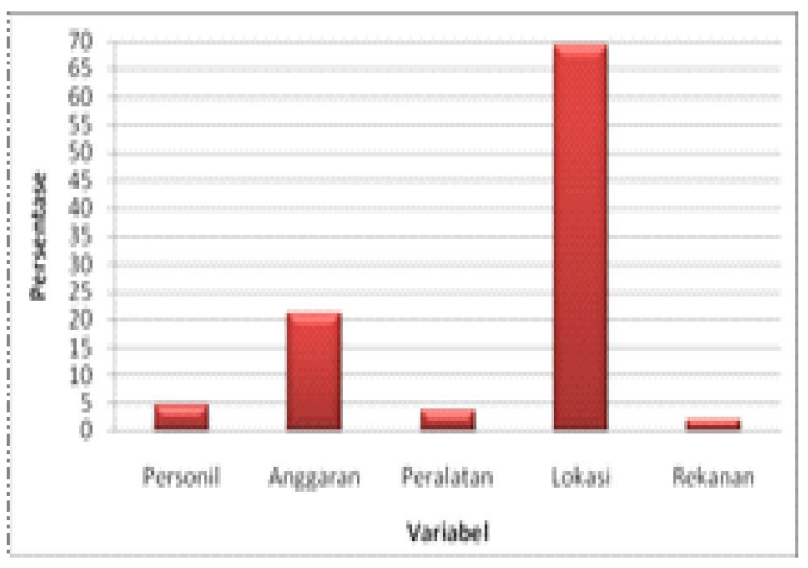

Gambar 4. Adapun persentase faktor dominan yang mempengaruhi kinerja PPK berdasarkan tingkat kepentingan.

\section{Cara Meningkatkan performa PPK agar mencapai target sesuai kontrak kinerja}

Secara umum hal-hal yang dapat dilakukan untuk meningkatkan performa PPK sesuai dengan manajemen pengembangan sumber daya manusia adalah :

\section{Pengembangan dan evaluasi PPK (Development and evaluation).}

Pejabat Pembuat Komitmen (PPK) dalam Satker PJN baik dalam penyelenggaraan pembangunan jalan, pelebaran jalan ataupun pemeliharan, harus menguasai pekerjaan yang menjadi tugas dan tanggungjawabnya. Untuk itu diperlukan suatu pembekalan agar PPK yang ada dapat lebih menguasai dan ahli di bidangnya masing-masing serta meningkatkan kinerja yang ada. Dengan begitu proses pengembangan dan evaluasi PPK menjadi sangat penting.

Evaluasi kinerja PPK oleh pemerintah telah diupayakan melalui kontrak kinerja, akan tetapi belum 
ada realisasi terhadap evektivitas daro kontrak kinerja tersebut, untuk itu pengawasan dan evaluasi secara berkala sangat perlu dilakukan, untuk mengetahui sejauh mana pengembangan kinerja PPK.

\section{Memberikan kompensasi dan proteksi pada Pejabat Pembuat Komitme (PPK) (Compensation and protection).}

Kompensasi adalah imbalan atas kontribusi kerja pegawai secara teratur dari organisasi atau perusahaan. Kompensasi yang tepat sangat penting dan disesuaikan dengan kondisi pasar tenaga kerja yang ada pada lingkungan eksternal. Kompensasi yang tidak sesuai dengan kondisi yang ada dapat menyebabkan masalah ketenaga kerjaan di kemudian hari atau pun dapat menimbulkan kerugian pada organisasi atau perusahaan. PPK yang telah memenuhi standart kerja atau telah menyelesaikan progress kerjanya secara tepat, akurat dan tepat waktu perlu diberikan reward oleh pemerintah ataupun pejabat yang berwenang sehingga hal tersebut menjadi motivasi bagi PPK lainnya untuk terus menjadi lebih baik.

\section{Memberikan Proteksi dan Jaminan Keselamatan Kerja kepada Pejabat Pembuat Komitmen (PPK)}

Pemberian proteksi atau perlindungan juga perlu diberikan kepada Pejabat Pembuat Komitmen (PPK) agar dapat melaksanakan pekerjaannya dengan tenang sehingga kinerja dan kontribusi perkerja PPK dapat tetap maksimal dari waktu ke waktu.

\section{KESIMPULAN DAN SARAN}

Berdasarkan analisis dan hasil penelitian, maka dapat disimpulkan hal-hal sebagai berikut:

- Faktor yang paling dominan yang menjadi penentu Pejabat Pembuat Komitmen (PPK) dalam meningkatkan performa mereka dilihat dari segi kepuasan adalah faktor lokasi sebesar 55,124\%, faktor peralatan sebesar $19,034 \%$, faktor anggaran sebesar 15,718\%, faktor personil sebesar $6,716 \%$ dan faktor rekanan sebesar 3,408\%. Hasil penelitian ini didukung oleh pernyataan Tiong Iskandar, dalam jurnalnya yang berjudul analisisa kinerja operator alat berat pada pekerjaan galian timpunan pada proyek pembangunan jalan jalur lintas selatan, dinyatakan bahwa lokasi adalah faktor terpenting dalam hal penentu jumlah dan kapasitas alat berat yang digunakan sehingga mempengaruhi mutu, biaya dan waktu suatu proyek.

- Sedangkan jika dilihat dari segi kepentingan adalah faktor lokasi sebesar $69,252 \%$, faktor anggaran sebesar $20,992 \%$, faktor personil sebesar 4,426\%, faktor peralatan sebesar $3,523 \%$ dan faktor rekanan $(1,807 \%)$. Dengan korelasi keduanya, antara tingkat kepuasan dengan tingkat kepentingan adalah semakin penting faktor tersebut bagi PPK maka factor tersebutlah yang menjadi penentu dalam kepuasan kerja mereka.

- Faktor yang paling dominan yang menjadi penentu Pejabat Pembuat Komitmen (PPK) dalam meningkatkan performa mereka menurut peniliauan Kordinator Lapangan adalah faktor peralatan sebesar 98,042\%, faktor PPK sebesar 95,589\%, faktor rekanan sebesar $88,002 \%$, faktor anggaran dan lokasi sebesar 74,757\% dan faktor personil sebesar $54,281 \%$.

- Cara meningkatkan performa PPK agar mencapai target sesuai Kontrak Kinerja adalah meningkatkan kualitas kepemimpinan PPK yang dalam hal ini berkaitan dengan inisiatif, keyakinan dalam diri, pertanggungjawan, komunikasi antar semua pekerja dan komunikasi. Adapun cara yang dapat dilakukan adalah Pengembangan dan evaluasi PPK (Development and evaluation), Memberikan kompensasi dan proteksi pada Pejabat Pembuat Komitme (PPK) (Compensation and protection), Memberikan Proteksi dan Jaminan Keselamatan Kerja kepada Pejabat Pembuat Komitmen (PPK).

Adapun saran yang dapat diberikan berdasarkan pembahasan dan kesimpulan adalah sebagai berikut:

- Pejabat Pembuat Komitmen (PPK) yang bertanggung jawab penuh terhadap proyek, sebaiknya memahami dengan jelas apa yang menjadi kewajiban, tanggung jawab dan haknya. Dengan mulai berlakunyya kontrak 
kinerja sejak tahun 2010, hendaknya menjadi motivasi kerja bagiPPK untuk meningkatkan kinerja dan performa sehingga proyek dapat tercapai dengan target yang maksimal.

- Pemerintah pusat hendaknya memperhatikan dengan jelas paket kerja/proyek yang akan dibagikan kepada satker. PPK sebagai pelaksana, sudah pastinya menjadi perhatian pemerinatah yang bertungas memonitor progress kerja, bukan hanya penilaian dilakukan berdasarkan kontrak kinerja yang dinilai pada akhir proyek. Penilaian juga perlu dilakukan secara berkala.

- Pemberian kompensasi, bonus, jaminan keselamatan kerja terhadap semua pekerja juga harus menjadi bagian penting, karena semakin terjaminnya kesejahteraan pekerja sudah tentu mereka akan bekerja dengan maksimal.

\section{DAFTAR PUSTAKA}

Asiyanto. 2004. Manajemen Produksi untuk Jasa Konstruksi. Jakarta: PT. Pradnya Paramita.

Budiharjo, A. 2004. Hubungan antara Strategi Bisnis dan Strategi SDM dalam Upaya Meningkatkan Kinerja Perusahaan. Usahawan. No. 03 Th. XXXIII.

E. Neal Jr. James. 2004. Panduan Evaluasi Kinerja Karyawan. Jakarta: Prestasi Pustaka.

Evianto, Wulfram. 2005. Manajemen Proyek Konstruksi. Yogyakarta: Andi.

Fahri, Faisal. 2009. Pengaruh Sertifikasi Terhadap Kinerja Perusahaan Jasa Konstuksi Golongan Kecil di Kabupaten Jembara-Bali. Skripsi tidak diterbitkan. Malang: Fakultas Teknik Universitas Negeri Malang.

Hasibuan, H. Malayu. 2002. Manajemen Sumber Daya Manusia. Edisi Refisi. Jakarta: Bumi Aksara.

Iskandar ,Tiong. 2010. Analisa Kinerja Operasional Penggunaan Alat-Alat Berat Pada Pekerjaan Galian Timbunan Pada
Proyek Pembangunan Jalan Jalur Lintas Selatan. Jurnal Sondir Nomor 2 Volume IV April : Institut Teknologi Nasional Malang.

Kusbinarti. 2006. Analisis Strategi Pengembangan Tenaga Kerja untuk Meningkatkan Produktivitas Kerja Karyawan pada PT. Pos Indonesia (persero) Kantor Pos Trenggalek. Skripsi. Malang: Universitas Negeri Malang.

Mangkunegara, Anwar prabu. 2005. Evaluasi Kinerja Sumber Daya Manusia. Edisi Pertama. Bandung: PT. Refika Aditama.

Sugiyono. 2010. Memahami Penelitian Kualitatif. Alfabeta.Bandung. 